\title{
Grazing by Pyrosoma atlanticum (Tunicata, Thaliacea) in the south Indian Ocean
}

\author{
R. Perissinotto ${ }^{1, *}$, P. Mayzaud ${ }^{2}$, P. D. Nichols ${ }^{3}$, J. P. Labat ${ }^{2}$ \\ ${ }^{1}$ School of Biological \& Conservation Sciences, G. Campbell Building, University of KwaZulu-Natal, \\ Howard College Campus, Durban 4041, South Africa \\ ${ }^{2}$ Océanographie Biochimique, Observatoire Océanologique, LOV-UMR CNRS 7093, BP 28, 06230 Villefranche-sur-Mer, France \\ ${ }^{3}$ Commonwealth Scientific and Industrial Research Organisation (CSIRO), Marine and Atmospheric Research, \\ Castray Esplanade, Hobart, Tasmania 7001, Australia
}

\begin{abstract}
Pyrosomas are colonial tunicates capable of forming dense aggregations. Their trophic function in the ocean, as well as their ecology and physiology in general, are extremely poorly known. During the ANTARES-4 survey (January and February 1999) their feeding dynamics were investigated in the south Indian Ocean. Results show that their in situ clearance rates may be among the highest recorded in any pelagic grazer, with up to $35 \mathrm{l} \mathrm{h}^{-1}$ per colony (length: $17.9 \pm$ 4.3 [SD] cm). Gut pigment destruction rates, estimated for the first time in this tunicate group, are higher than those previously measured in salps and appendicularians, ranging from 54 to virtually $100 \%$ (mean: $79.7 \pm$ $19.8 \%$ ) of total pigment ingested. Although individual colony ingestion rates were high $(39.6 \pm 17.3$ [SD] $\mu \mathrm{g}$ pigment $\mathrm{d}^{-1}$ ), the total impact on the phytoplankton biomass and production in the Agulhas Front was relatively low, 0.01 to $4.91 \%$ and 0.02 to $5.74 \%$ respectively, as a result of the low abundance of colonies. Colonies showed higher retention efficiency for particles larger than $10 \mu \mathrm{m}$. Low levels of lipids and percentages of triacylglycerols and free fatty acids were found in zooids. Markers for diatoms (C16 PUFA), dinoflagellates (22:6n-3, 18:5n-3) and prymnesiophytes (18:1n-9, 18:4n-3) were observed. Stepwise discriminant analysis of published data on phytoplankton fatty acid showed a strong similarity between the composition of the 2 neutral lipid classes found in $P$. atlanticum and that of both dinoflagellates and prymnesiophytes. The sterol composition confirmed this result with the contribution of 24-methylcholest-5,22-dien-3 $\beta$-ol, cholesterol, 24-methylenecholesterol and 24-ethylcholesterol. Colonies exhibited large numbers of ciliate protozoans (possibly Strombidium sp.). It is not clear whether this constituted a mere opportunistic intrusion, or rather a more stable association between the 2 organisms.
\end{abstract}

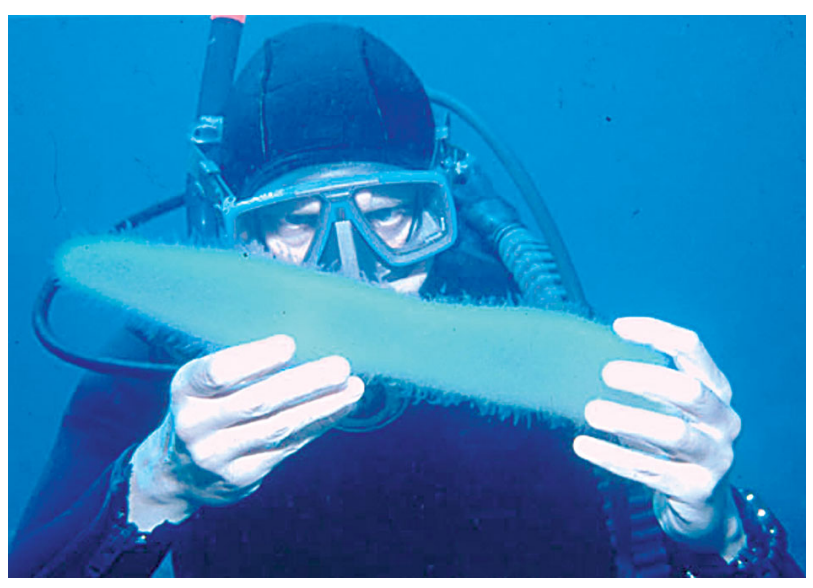

The pelagic tunicate Pyrosoma atlanticum conducts diel vertical migrations. Employing continuous jet propulsion, its colonies attain clearance rates that are among the highest in any zooplankton grazer. However, internal lipid accumulation is limited, and colonies use high biomass turnover as an alternative to energy storage.

Photo: Peter Wirtz

KEY WORDS: Pyrosoma - Pelagic tunicates · Gut pigment content - Gut turnover time - Ingestion rates · Clearance rates · Lipid content · Agulhas Front Resale or republication not permitted without
written consent of the publisher

\section{INTRODUCTION}

Pyrosomas are a small group of holoplanktonic tunicates, currently including only 8 described species and 3 genera (van Soest 1981). They are restricted to the warmer open ocean waters, between approximately $50^{\circ} \mathrm{N}$ and $50^{\circ} \mathrm{S}$ in all oceans (van Soest 1981). They are 
the least studied among pelagic tunicates, especially in terms of feeding, energetics and physiological processes in general (Madin \& Deibel 1998).

A recent review (Harbison 1998) and subsequent work have shown that, while in the past the trophic role of pyrosomas in oceanic ecosystems have been largely overlooked, they are actually a very important prey item in the diet of many marine animals, vertebrates in particular. Harbison (1998) lists 62 fish and 3 turtle species that worldwide use pyrosomes as a significant food source. To this list, 2 albatross and 1 sea lion species from New Zealand and Australian waters have been added more recently (James \& Stahl 2000, Childerhouse et al. 2001, Hedd \& Gales 2001). Amongst the invertebrates, at least 1 species of sapphirinid copepod (Harbison 1998), 2 genera of hyperiid amphipods (Trégouboff \& Rose 1957) and another 2 of penaeid shrimps (Monticelli \& Lo Bianco 1901, Lindley et al. 2001) have been found inside pyrosoma colonies. Three species of ciliate protozoans have also been reported as parasitic hosts inside pyrosomas (Harbison 1998).

Much less understood are the feeding dynamics of pyrosomas. Some basic studies of anatomical and mechanical aspects of their feeding mechanisms have been conducted. These show that within the pharyngeal cavity, the stigmatal cilia of the branchial basket move continuously to propel seawater in a fixed direction (Martinucci et al. 1992). Apart from making pyrosomas the only known animal that uses continuous jet propulsion (Bone 1998), this continuous pump action also supplies each zooid with oxygen for respiration and particles for its feeding requirements. Food particles are retained by mucus produced by the ventral endostyle. Eventually, the entire mucous sheet with the captured particles is rolled into a cord and moved posteriorly to the oesophagus for digestion (Madin \& Deibel 1998).

There is, however, an extreme scarcity of available information on their ingestion and clearance rates, particle/prey selectivity, and impact rates on planktonic biomass and production. The recent study carried out in the southeast Atlantic by Drits et al. (1992) is the only source of information currently available in this respect. These authors studied a Pyrosoma atlanticum population of small colonies (5 to $6.5 \mathrm{~cm}$ length) and, although they made some preliminary measurements of $P$. atlanticum ingestion rates and impact on the local phytoplankton community, the focus of their work was mainly on faecal pellet production and its contribution to vertical carbon flux (Drits et al. 1992).

During the last leg of the ANTARES-4 cruise to the south Indian and the Southern oceans, Pyrosoma atlanticum colonies in the size range of 7.5 to $24 \mathrm{~cm}$ were observed in the region north of the Subtropical Front.
This prompted an opportunistic investigation over a period of about $2 \mathrm{wk}$. The main aims of the study were: (1) to obtain some basic estimates of in situ ingestion and clearance rates for this species; (2) to estimate its impact on primary biomass and production in the area; and (3) to analyze its dietary preferences on the basis of particle size selectivity and lipid composition.

\section{MATERIALS AND METHODS}

All samples and measurements were taken during the ANTARES-4 cruise aboard the RV 'Marion Dufresne', during the period 5 January to 23 February 1999. The operational area was restricted between approximately 43 to $46^{\circ} \mathrm{S}$ and 61 to $65^{\circ} \mathrm{E}$, in the Indian sector of the Southern Ocean and the region of the Agulhas Front (Fig. 1). The survey consisted mainly of an intensive grid of lines and 3 long-term stations (Stns 3, 7 and 8), each occupied for a period of 3 to $6 \mathrm{~d}$. Pyrosoma atlanticum was collected only in the Agulhas Front region, north of the Subtropical Convergence, during the period 2 to 16 February at Stns G4, 7 and 8 (Fig. 1).

Specimens were collected using 3 different types of gear: a $160 \mathrm{~cm}$ diameter Omori Net (1000 $\mu \mathrm{m}$ mesh), a $67 \mathrm{~cm}$ diameter Bongo Net ( $\times 2: 200$ and $500 \mu \mathrm{m}$ mesh) and a $57 \mathrm{~cm}$ diameter WP-2 system $(\times 3$ : all $200 \mu \mathrm{m}$ mesh). Tows with the Omori and Bongo nets were made obliquely, from 100 to $200 \mathrm{~m}$ to the surface, while the WP-2 system was towed vertically from $200 \mathrm{~m}$ to the surface. At each station, net tows were repeated at 4 to $5 \mathrm{~h}$ intervals to study diel variations in abundance and gut pigment contents.

Samples for chlorophyll a ( $\mathrm{chl}$ a) determination were collected using a 24 bottle rosette (General Oceanics). Size-fractionated chl a concentrations were obtained with parallel filtration of $500 \mathrm{ml}$ samples through $20 \mu \mathrm{m}$ nylon, 10 and $2 \mu \mathrm{m}$ polycarbonate (Nuclepore) as well as through GF/F glass-fibre (Whatman) filters (Fiala et al. 2004). Pigments were extracted from each filter in $90 \%$ acetone and fluorescence measured on a PerkinElmer MPF 66 spectrofluorometer. Phytoplankton production rates were measured in the upper 125 m layer, using photosynthesis-irradiance (P-I) curves obtained from short-term incubations in a photosynthetron apparatus and following the methodology described in Clementson et al. (1998).

Ingestion rates of Pyrosoma atlanticum on the autotrophic material available in the region were estimated using the combination of simultaneous measurements of gut pigment contents $(G)$, gut evacuation rates $(k)$ and gut pigment destruction $\left(b^{\prime}\right)$ (Perissinotto et al. 1997, Tirelli \& Mayzaud 1998). Gut pigment contents were measured in freshly collected individuals after $24 \mathrm{~h}$ extraction in $250 \mathrm{ml}$ of $90 \%$ acetone solution. The 


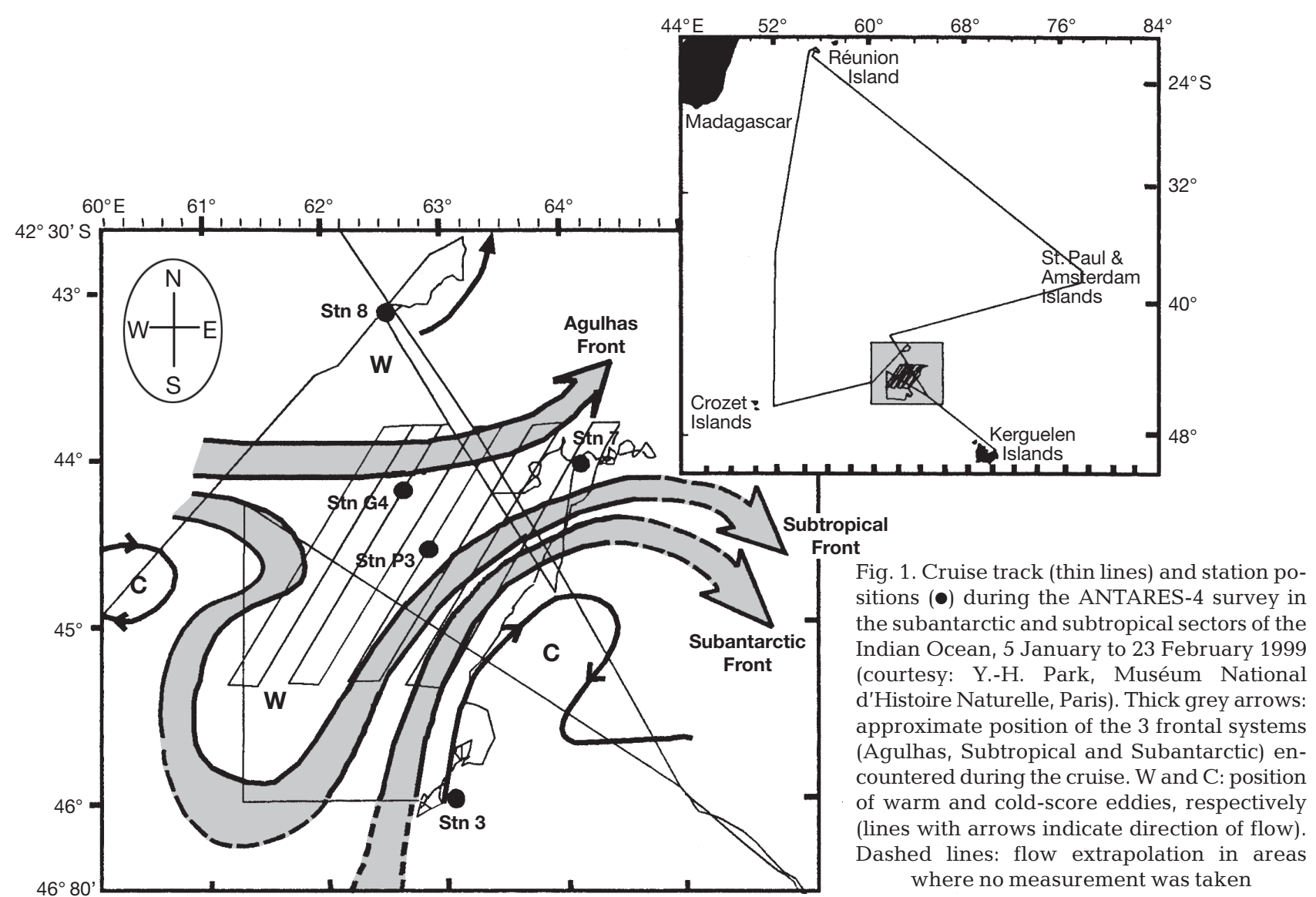

pigment content of the supernatant was measured after centrifugation with a Turner Designs fluorometer, before and after acidification with $1 \mathrm{~N} \mathrm{HCl}$. Chl $a$ and phaeopigment concentrations were added together and expressed in units of chl a equivalents (Conover et al. 1986). Because the length of the pyrosoma colonies collected during the study varied widely, from about 7.5 to $24 \mathrm{~cm}$, total pigments extracted were normalized to a standard length of $1 \mathrm{~cm}$ (i.e. total pigment content of colony divided by total colony length) prior to comparative analyses.

Gut evacuation rates were estimated by incubating in $0.2 \mu \mathrm{m}$-filtered seawater Pyrosoma atlanticum freshly caught during night tows. Small amounts of non-fluorescing cornstarch were added to keep the $P$. atlanticum under continuous feeding conditions (Perissinotto \& Pakhomov 1998). The incubation period was $6 \mathrm{~h}$ and the decline in gut pigment content was monitored at intervals of 15 to $30 \mathrm{~min}$ for the first $2 \mathrm{~h}$ and of $60 \mathrm{~min}$ thereafter. Gut evacuation rates $\left(\mathrm{h}^{-1}\right)$ were derived from the slope of the regression of the natural log of gut pigments versus time (Dam \& Peterson 1988). Loss of pigments to non-fluorescent end products by stomach digestion was estimated at the 2 long-term stations, Stns 7 and 8. Two independent measurements of pigment loss were made on each occasion following the 2-compartment protocol described by Perissinotto et al. (1997). The method consisted of a comparison of the pigment budget of a control versus an experimental volume of natural water, in which $P$. atlanticum were allowed to feed for a fixed period of time. Any significant loss in the pigment budget from the experimental treatment was attributed to gut destruction of phytoplankton pigments. To avoid as much as possible problems associated with the production of faecal pellets, the incubation time was restricted to $1 \mathrm{~h}$, i.e. shorter than the estimated gut turnover time of $1.43 \mathrm{~h}$ (Fig. 2).

In the size-selectivity experiments, 4 replicates of one Pyrosoma antlanticum each (length: 9 to $20 \mathrm{~cm}$ ) were incubated in $10 \mathrm{l}$ of natural seawater for periods of 1 to $8 \mathrm{~h}$, in darkness and at ambient temperature (13.7 to $17.8^{\circ} \mathrm{C}$, depending on station) on deck. Duplicate water samples of $500 \mathrm{ml}$ were taken from each container at the beginning and end of the incubation for chl $a$ and phaeopigment analysis. Two size-classes of phytoplankton ( $>10$ and $<10 \mu \mathrm{m}$ ) were obtained by serial filtration on a Millipore manifold. Nuclepore $(10 \mu \mathrm{m})$ and Whatman GF/F filters were used for this purpose. Pigments from the different filters were 


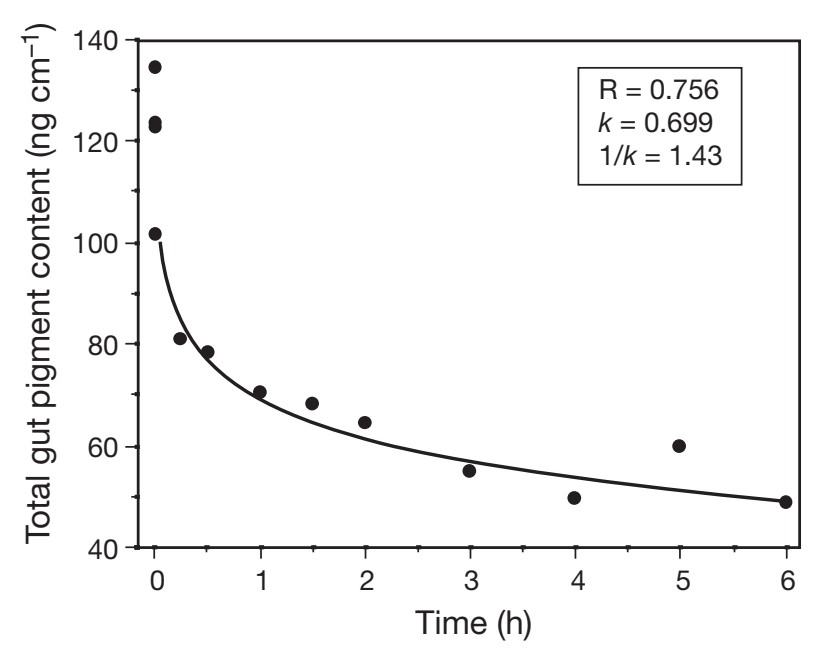

Fig. 2. Pyrosoma atlanticum. Estimation of gut evacuation rate $(k)$ and turnover time $(1 / \mathrm{k})$ of colonies standardized to $1 \mathrm{~cm}$ length. Pyrosomas collected at Stn 8, on 14 February 1999 with drifting Omori and Bongo nets. Gut pigment content at time $0 \mathrm{~h}\left(G_{0}\right)=120 \pm 13.7(\mathrm{SD})\left(\mathrm{ng} \mathrm{chl}\right.$ a-equiv.) $\mathrm{cm}^{-1}$

extracted for $24 \mathrm{~h}$ in $8 \mathrm{ml}$ of $90 \%$ acetone and concentrations were calculated from fluorescence measured with a Turner Designs fluorometer.

Pyrosoma samples for lipid extraction and profiling were isolated individually and deep frozen $\left(-80^{\circ} \mathrm{C}\right)$. Upon return to the laboratory, size was measured before lipid extraction according to the method of Bligh \& Dyer (1959). After solvent evaporation at high vacuum, the extracted lipids were weighted in tarred vials and the lipid extracts placed in liquid nitrogen at $-70^{\circ} \mathrm{C}$ until analysis. Lipid classes were quantified after chromatographic separation coupled with flame ionization detection (FID) on an Iatroscan Mark IV TH 10 (Ackman 1981), as described by Mayzaud et al. (2003).

Lipid classes were further isolated by preparative thin-layer chromatography (TLC), using n-hexane: ether:acetic acid (170:30:2 by vol.). After development, the bands of neutral lipids were recovered, eluted with diethyl ether:chloroform $(1: 1 \mathrm{v} / \mathrm{v})$, dried under high vacuum and weighed. Fatty acid methyl esters of total lipids were prepared with $7 \%$ boron trifluoride in methanol (Morrison \& Smith 1964). Gas chromatography (GC) of all esters was carried out on a $30 \mathrm{~m}$ length $\times 0.32 \mathrm{~mm}$ internal diameter quartz capillary column coated with Famewax (Restek) in a Perkin-Elmer XL Autolab gas chromatograph (Mayzaud et al. 2003). Analysis of sterols was conducted on an aliquot of the separated sterol fraction after conversion to trimethylsilyl (TMSi) ethers using N,O-bis-(trimethylsilyl)trifluoroacetamide (BSFA, $50 \mu \mathrm{l}$ ) at $60^{\circ} \mathrm{C}$ for $1 \mathrm{~h}$. GC and GC-MS analysis of sterols was performed according to the procedure described in Jeffs et al. (2004).
The analysis of predator-prey relationships (dietary origin of neutral lipids) was performed using stepwise linear discriminant analyses (LDA). To achieve meaningful comparisons between fatty acid (FA) patterns from potential prey species of phytoplankton and Pyrosoma atlanticum lipids, a database was built using the majority of published studies on cultured phytoplankton species (Mayzaud unpubl.), including 104 FA profiles of marine diatoms, 36 of marine prymnesiophytes, 36 of marine dinoflagellates and 21 of marine chlorophytes. Wilks' $\lambda$ was used to indicate the effectiveness of the discriminant analysis in separating groups, with smaller values indicating greater success. Potential preys were then classified by LDA. The outliers (high leverage and low residual standard deviation) were removed and a discriminant model was defined, after verification of the homogeneity of FA profiles with the use of Mahalanobis distance and a chi-squared test. The number of significant descriptors considered in the LDA model was decreased to 16 discriminant FA, using a stepwise forward procedure. The percent of cases correctly classified was used to evaluate the performance of the classification function. The predicted group membership of individuals based on the classification function was examined to determine into which group individuals were misclassified. FA profiles of $P$. atlanticum from triacylglycerols (TG) and free FA were then added to the model to define predicted group membership of the pyrosoma dietary indicators with one of the pre-existing prey group. As normality was presupposed for most of these analyses, percentages were normalised using the arcsine transformation (Zar 1984).

\section{RESULTS}

\section{Pyrosoma atlanticum and its trophic environment}

During the ANTARES-4 cruise, Pyrosoma atlanticum was observed only in the region between the Subtropical Front (STF) and the Agulhas Front (AF), at Stns G4 and 7, and then again at Stn 8, north of the AF (Fig. 1). Maximum concentrations were found at G4, where on one occasion (2 February, 10:30 h local time) levels of about 14.2 colonies $\mathrm{m}^{-2}$ were recorded in the upper $100 \mathrm{~m}$ (Table 1). Average values obtained from multiple oblique and/or vertical hauls made with the Omori, Bongo and WP-2 nets were $0.11 \pm 0.14$ (SD) colonies $\mathrm{m}^{-2}$ at $\mathrm{Stn} 7$ and $0.10 \pm 0.12(\mathrm{SD})$ colonies $\mathrm{m}^{-2}$ at $\mathrm{Stn} 8$. Colonies were all in the range of 7.5 to $24 \mathrm{~cm}$ total length, with an average length of $12.1 \pm 4.22$ (SD) $\mathrm{cm}$ (Table 1).

Chl a concentrations in the region around the STF and the AF were in the range of 0.4 to $0.7 \mu \mathrm{g} \mathrm{l}^{-1}$ and 0.3 to $0.45 \mathrm{\mu g} \mathrm{l}^{-1}$, respectively (Perissinotto et al. 2001, 
Table 1. Pyrosoma atlanticum. Mean abundance, colony (col.) length and grazing activity in the upper $100 \mathrm{~m}$ at the 3 stations occupied in the region of the Agulhas Front during the ANTARES-4 survey in February 1999. Ingestion and filtration rates were obtained using a gut turnover time of $1.43 \mathrm{~h}$ and a gut pigment destruction factor of 0.797 . L: length; G: gut pigment content; $I$ : ingestion rate; F: filtration rate; B: phytoplankton biomass; PP: primary production. Impact on primary production was estimated assuming a chl a:C ratio of 1:50. n: number of observations. -: no available data; $L$ and $G$ : mean \pm SD

\begin{tabular}{|c|c|c|c|c|c|c|c|c|c|c|c|}
\hline \multirow{2}{*}{$\begin{array}{l}\text { Stn } \\
\text { no. }\end{array}$} & \multirow[t]{2}{*}{ Date } & \multirow{2}{*}{$\begin{array}{c}\mathrm{B} \\
\underset{(\mathrm{mg} \mathrm{chl} a}{\left.\mathrm{m}^{-2}\right)}\end{array}$} & \multirow{2}{*}{$\begin{array}{c}\mathrm{PP} \\
\left(\mathrm{mgC} \mathrm{m}^{-2} \mathrm{~d}^{-1}\right)\end{array}$} & \multirow[b]{2}{*}{$\mathrm{n}$} & \multirow[b]{2}{*}{$\begin{array}{l}\text { Abund. } \\
\left(\text { col. m }{ }^{-2}\right)\end{array}$} & \multirow[b]{2}{*}{$\begin{array}{c}L \\
(\mathrm{~cm})\end{array}$} & \multirow{2}{*}{$\begin{array}{c}\text { Pyro } \\
G \\
\left(\mu \mathrm{g} \mathrm{col}^{-1}\right)\end{array}$} & \multirow{2}{*}{$\left(\mu \mathrm{g} \mathrm{col} .^{-1} \mathrm{~d}^{-1}\right)$} & \multirow[b]{2}{*}{$\begin{array}{c}F \\
\left(1 \mathrm{col}^{-1} \mathrm{~d}^{-1}\right)\end{array}$} & \multirow{2}{*}{\multicolumn{2}{|c|}{ Impact on }} \\
\hline & & & & & & & & & & & $\begin{array}{l}\text { act on } \\
\text { PP (\%) }\end{array}$ \\
\hline G4 & Feb 20 & 20.21 & 864 & 3 & 14.2 & $17.9 \pm 4.3^{\mathrm{a}}$ & $1.56 \pm 0.49$ & 69.91 & 346 & 4.91 & 5.74 \\
\hline \multirow[t]{2}{*}{7} & Feb 60 & 20.65 & 691 & 1 & 2.11 & 20 & 1.44 & 49.62 & 240 & 0.51 & 0.76 \\
\hline & Feb 10 & 25.17 & 845 & 1 & 0.06 & 13 & 1.26 & 43.39 & 172 & 0.01 & 0.02 \\
\hline \multirow[t]{5}{*}{8} & Feb 12 & 16.09 & 851 & 2 & 0.51 & $11.2 \pm 2.8$ & $1.48 \pm 0.37$ & 50.96 & 317 & 0.16 & 0.15 \\
\hline & Feb 13 & 13.67 & 613 & 2 & 0.75 & $14.7 \pm 8.1$ & $0.44 \pm 0.24$ & 15.15 & 111 & 0.08 & 0.09 \\
\hline & Feb 14 & 36.86 & 10880 & 4 & 3.19 & $9.3 \pm 1.5$ & $0.98 \pm 0.16$ & 33.74 & 91.5 & 0.29 & 0.49 \\
\hline & Feb 15 & 14.55 & 590 & 1 & 0.25 & 18 & 0.806 & 27.75 & 191 & 0.05 & 0.06 \\
\hline & Feb 16 & 16.22 & - & 2 & 0.50 & $11.3 \pm 2.5$ & $0.77 \pm 0.17$ & 26.51 & 163 & 0.08 & - \\
\hline
\end{tabular}

Fiala et al. 2004). Vertical profiles showed the consistent occurrence of a deep chl a maximum (DCM) positioned at about 30 to $60 \mathrm{~m}$ throughout the STF-AF area. Chl a levels within the DCM ranged from about 0.4 to $0.6 \mu \mathrm{g} \mathrm{l}^{-1}$ at $\operatorname{Stn} 8$ to 0.7 to $0.8 \mu \mathrm{g}^{-1}$ at $\operatorname{Stn} 7$ (Perissinotto et al. 2001). Integrated (0 to $100 \mathrm{~m}$ ) watercolumn chl a levels, at the 3 stations where Pyrosoma atlanticum was collected, varied from 13.7 to $36.9 \mathrm{mg}$ $\mathrm{m}^{-2}$ (Table 1). The 2 broad chl a fractions used in the size-selectivity experiments with $P$. atlanticum,$<10 \mu \mathrm{m}$ and $>10 \mu \mathrm{m}$, were represented in the average proportions of $77.4 \pm 7.51(\mathrm{SD}) \%$ and $24.3 \pm 6.07(\mathrm{SD}) \%$ of the total chl $a$, respectively. Phytoplankton production rates normalized to the upper $100 \mathrm{~m}$ layer ranged between 590 and $1088 \mathrm{mg} \mathrm{C} \mathrm{m}{ }^{-2} \mathrm{~d}^{-1}$ (average: $792 \pm$ $174 \mathrm{mg} \mathrm{C} \mathrm{m}^{-2} \mathrm{~d}^{-1}$ ) (Table 1, F. B. Griffiths unpubl.).

\section{Feeding dynamics of Pyrosoma atlanticum}

Total gut pigment contents $(G)$ per individual pyrosoma colony ranged from $303 \mathrm{ng}_{\text {colony }}{ }^{-1}$ (10 cm length) to $1586 \mathrm{ng}$ colony ${ }^{-1}$ (14 $\mathrm{cm}$ length). With the relatively small number of individual colonies available for in situ pigment measurement $(n=13)$, the relationship between total gut pigments and total colony length did not attain significance when day and night data were pooled (Fig. 3). However, bootstrap correlation coefficients for separate daytime and nighttime data revealed a significant correlation for the daytime series $\left(\mathrm{r}^{2}=0.411, \mathrm{n}=8\right.$, $\mathrm{p}<0.05)$. A highly significant difference between daytime and nighttime gut pigment contents was obtained when values were normalized to a standard colony length of $1 \mathrm{~cm}$ (Student's $t$-test, $t=4.05, \mathrm{p}<0.01$ ). The $1 \mathrm{~cm}$-standardized values ranged from 30.3 to $134 \mathrm{ng}$ $\mathrm{cm}^{-1}$ (average: $88.6 \pm 36.8$ [SD] ng cm${ }^{-1}$ ), with the highest levels found in colonies collected during the night.
The only gut evacuation experiment successfully completed during the study resulted in an estimated $k$ value of $0.699 \mathrm{~h}^{-1}$, and therefore a gut turnover time $(1 / k)$ of about $1.4 \mathrm{~h}$ (Fig. 2). Results obtained with the 4 gut pigment destruction incubations, over a period of $1 \mathrm{~h}$, showed that amounts in the range of 54 to $100 \%$ (average: $79.7 \pm 19.8$ [SD] \%) of total pigment ingested were actually degraded to non-fluorescent end products by pyrosoma colonies. Therefore, the dimensionless factor required for the adjustment of total pigment ingested by colonies per unit time, $1-b^{\prime}$ (Conover et al. 1986, Perissinotto 1992, Bochdansky et al. 1998), is equal to 0.203 .

Size-selectivity by Pyrosoma atlanticum on the natural phytoplankton assemblage was consistently in favour of particles $>10 \mu \mathrm{m}$. At Stn 7, the decrease in

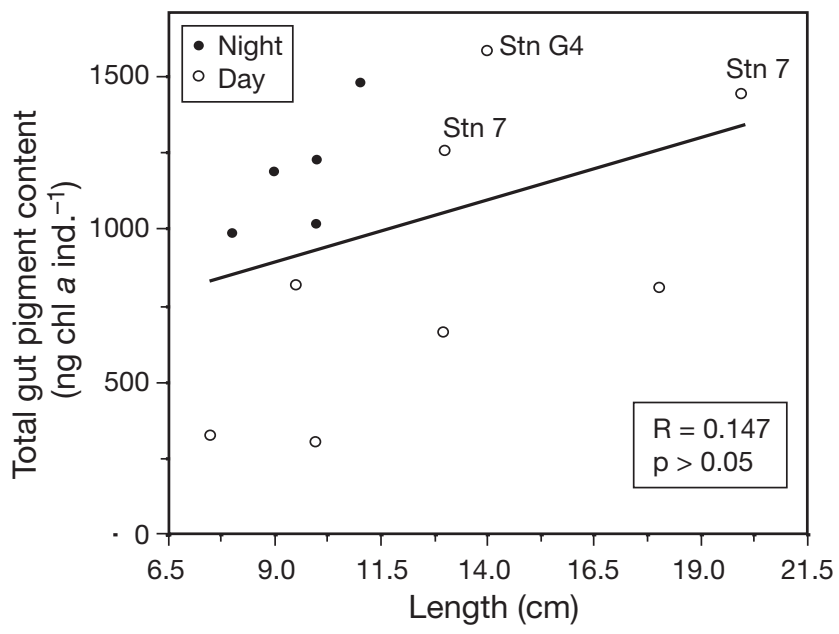

Fig. 3. Pyrosoma antlanticum. Total gut pigment content (chl $a+$ phaeopigments) extracted immediately after capture vs. total colony length. Symbols without station number indicate specimens collected at Stn 8. (0) Pyrosoma collected during daytime; $(\bullet)$ pyrosoma collected during nighttime 
Table 2. Pyrosoma atlanticum. Size-fractionated grazing on naturally occurring phytoplankton (Phytopl.) mixtures at Stns 7 and 8 of the ANTARES-4 survey. Percent decrease (Decr.) of the larger $(>10 \mu \mathrm{m})$ and smaller $(<10 \mu \mathrm{m})$ chl $a$ fractions is shown in relation to time since the start of incubation $\left(t_{0}\right)$. - : no data

\begin{tabular}{|c|c|c|c|c|c|c|c|c|c|c|c|c|}
\hline \multirow[t]{2}{*}{ Stn } & \multirow[t]{2}{*}{ Expt } & \multirow{2}{*}{$\begin{array}{l}\text { Pyrosoma } \\
\text { colony length } \\
\text { (cm) }\end{array}$} & \multirow{2}{*}{$\begin{array}{c}\text { Phytopl. } \\
(\mu \mathrm{m})\end{array}$} & \multirow{2}{*}{$\begin{array}{c}\text { Chl a } \\
\left(\mu \mathrm{g} \mathrm{l}^{-1}\right) t_{0}\end{array}$} & \multirow[b]{2}{*}{$\begin{array}{c}t_{1} \\
(\mathrm{~h})\end{array}$} & \multirow[b]{2}{*}{$\begin{array}{c}\text { Decr. } \\
(\%)\end{array}$} & \multirow[b]{2}{*}{$\begin{array}{c}t_{2} \\
\text { (h) }\end{array}$} & \multicolumn{2}{|c|}{ - Grazing - } & \multirow[b]{2}{*}{$\begin{array}{c}\text { Decr. } \\
(\%)\end{array}$} & \multirow[b]{2}{*}{$\begin{array}{c}t_{4} \\
(\mathrm{~h})\end{array}$} & \multirow[b]{2}{*}{$\begin{array}{r}\text { Decr } \\
(\%)\end{array}$} \\
\hline & & & & & & & & $\begin{array}{c}\text { Decr. } \\
(\%)\end{array}$ & $\begin{array}{r}t_{3} \\
(\mathrm{~h})\end{array}$ & & & \\
\hline \multirow[t]{4}{*}{7} & 1 & 20 & $>10$ & 0.089 & 1 & 15.2 & 2 & 24.2 & 8 & 84.8 & - & - \\
\hline & & & $<10$ & 0.207 & 1 & 12.3 & 2 & 24.6 & 8 & 27.7 & - & - \\
\hline & 2 & 13 & $>10$ & 0.085 & 1 & 3.57 & 2 & 10.7 & 8 & 42.9 & - & - \\
\hline & & & $<10$ & 0.223 & 1 & 5.56 & 2 & 12.5 & 8 & 23.6 & - & - \\
\hline \multirow[t]{4}{*}{8} & 3 & 9 & $>10$ & 0.033 & 1 & 0.00 & 2 & 8.33 & 3 & 16.7 & - & - \\
\hline & & & $<10$ & 0.141 & 1 & 5.77 & 2 & 11.5 & 3 & 11.5 & - & - \\
\hline & 4 & 10 & $>10$ & 0.017 & 0.25 & 8.61 & 0.5 & 11.7 & 0.75 & 15.6 & 1 & 22.1 \\
\hline & & & $<10$ & 0.105 & 0.25 & 6.41 & 0.5 & 10.3 & 0.75 & 10.3 & 1 & 10.3 \\
\hline
\end{tabular}

chl $a$ at the end of the incubation period $(8 \mathrm{~h})$ was in the range of 43 to $85 \%$ of the initial stock for the $>10$ fraction, but only 24 to $28 \%$ for the $<10 \mu$ fraction (Table 2). A similar pattern was observed at Stn 8, although the rates of decrease here were much lower (incubation period of only 1 to $3 \mathrm{~h}$ ) than those measured at $\operatorname{Stn} 7$, with 15.6 to $16.7 \%$ for the larger and 10.3 to $11.5 \%$ for the smaller fraction (Table 2).

Daily ingestion rates $(I)$ per individual colony ranged from 15.1 to $69.9 \mu \mathrm{g}$ pigment $\mathrm{d}^{-1}$ (average: $39.6 \pm 17.3$ [SD] $\mu \mathrm{g}$ pigment $\mathrm{d}^{-1}$ ). These are equivalent to a total impact on the local phytoplankton biomass and production of 0.01 to $4.91 \%$ and 0.02 to $5.74 \%$ (assuming a C:chl a ratio of 50), respectively. In terms of clearance rate $(F)$, individual colonies were able to process volumes in the range of 91 to 3461 colony $^{-1} \mathrm{~d}^{-1}$ (average: $204 \pm 91$ [SD] 1 colony $^{-1} \mathrm{~d}^{-1}$ ) (Table 1$)$.

The occurrence of high numbers of ciliate protozoans was observed in interstitial areas of freshly dissected colonies. Ciliate cells ranged from about 100 to $200 \mu \mathrm{m}$ in diameter and exhibited a highly motile behaviour under the microscope (Fig. 4). They were tentatively identified as members of the oligotrich genus Strombidium (W. Petz pers. comm.).

\section{Lipid composition of Pyrosoma atlanticum}

Six colonies of Pyrosoma atlanticum were analysed for their lipid content. The total length of the colonies varied from 18 to $25 \mathrm{~cm}$, while their mean dry weight was $2.01 \pm 0.7 \mathrm{~g}$ colony $^{-1}$. The average lipid content was $5.7 \pm 0.67 \%$ dry weight. Lipid class separation showed large dominance of polar lipids (>80\%), intermediate levels of sterols and equal low proportion of triacylglycerols and free fatty acids (Table 3). A detailed account of sterol and fatty acid composition of the triacylglycerol and free fatty acid fractions is provided elsewhere (Mayzaud et al. unpubl.). The sterol
Table 3. Pyrosoma atlanticum. Lipid class composition (\% total lipids)

\begin{tabular}{|lc|}
\hline Lipid class & Mean $\% \pm \mathrm{SD}$ \\
\hline Triacylglycerols & $3.52 \pm 0.80$ \\
Free fatty acids & $3.92 \pm 0.98$ \\
Sterols & $8.13 \pm 0.60$ \\
Diacylglycerols & $2.28 \pm 0.69$ \\
Polar lipids & $82.15 \pm 1.92$ \\
\hline
\end{tabular}

composition is limited to the major constituents and shows the dominance of 24-methylcholest-5,22-dien$3 \beta$-ol, cholesterol, 24-methylenecholesterol and, to a minor extent, 24-ethylcholesterol and cis-22-dehydrocholestanol (Table 4). The fatty acid composition is limited to the main components, and those retained by

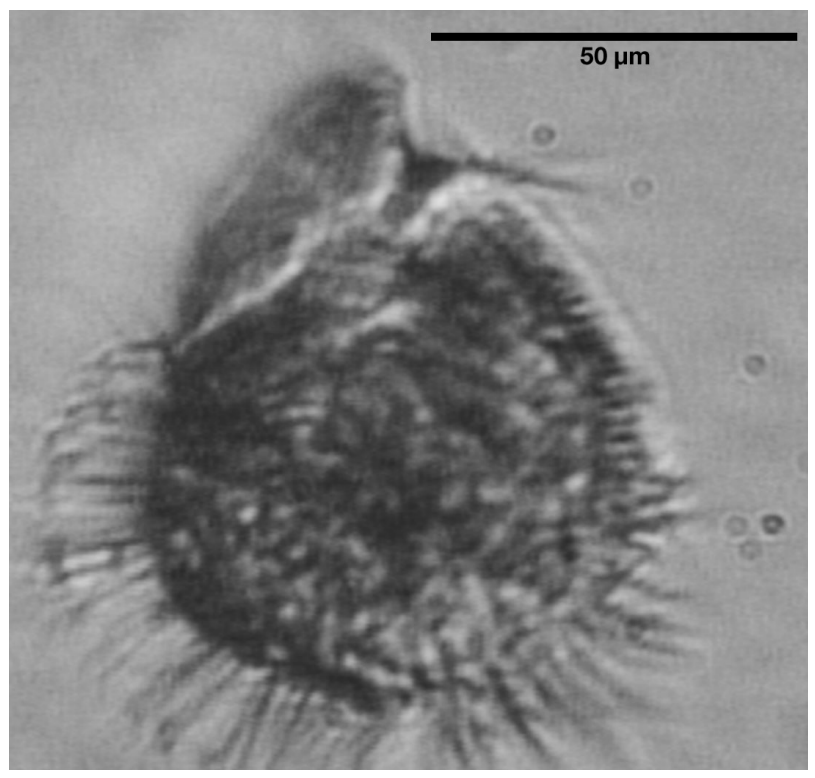

Fig. 4. Strombidium sp. Ciliate protozoan observed within a freshly dissected Pyrosoma atlanticum colony (photo: J.-P. Labat, February 1999) 
Table 4. Partial sterol composition of Pyrosoma atlanticum (\% of total sterols)

\begin{tabular}{|c|c|c|}
\hline Scientific name & Common name & $\%$ total \\
\hline Cholesta-5,22Z-dien-3ß-ol & Cis-22-dehydrocholesterol & 6.7 \\
\hline $5 \alpha$-cholest-22Z-en-3,-ol & Cis-22-dehydrocholestanol & 8.7 \\
\hline Cholest-5-en-3 $\beta$-ol & Cholesterol & 11.7 \\
\hline 24-methylcholesta-5, 22E-dien-3 $\beta$-ol & Brassicasterol/crinosterol & 22.7 \\
\hline 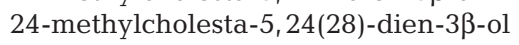 & 24-methylenecholesterol & 11.1 \\
\hline 24-ethylcholesta-5, 22E-dien-3 $\beta$-ol & Stigmasterol/poriferasterol & 3.9 \\
\hline 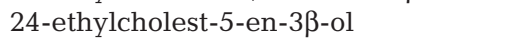 & Sitosterol/clionosterol & 8.3 \\
\hline Sterols24-ethylcholest-5-en-3 $\beta$-ol & Sitosterol/clionosterol & 26.8 \\
\hline Other & & 8.3 \\
\hline
\end{tabular}

the stepwise discriminant analysis of the phytoplankton data bank as significant contributors to the prediction model (Table 5). Both triacylglycerols and free fatty acids showed a tight relationship in terms of fatty acid profiles $\left(\mathrm{r}^{2}=0.753\right)$, suggesting a similar origin. Both were dominated by DHA (22:6n-3), 16:0, 18:4n-3, 14:0, EPA (20:5n-3), 18:1n-9, and 18:2n-6.

Stepwise discriminant analysis (SDA) on the fatty acid profiles of the main preys indicated that diatoms are best described by 16:1n-7, EPA (20:5n-3), C16 PUFA (16:3n-4, 16:2n-4, 16:4n-1, 16:2n-7), dinoflagellates by DHA (22:6n-3), 18:5n-3, 18:0, 16:0, prymnesiophytes by 18:1n-9, 18:4n-3, 22:5n-6 and iso-proportion of EPA and DHA, chlorophytes by $16: 3 n-3,16: 4 n-3$, 18:2n-6, 18:3n-3, 18:3n-6. The actual profiles for the 4 groups of phytoplankton considered are also presented in Table 5, to ease the comparison between prey and consumer fatty acid characteristics. Three

Table 5. Partial fatty acid composition (\% total fatty acids \pm SD) of the triacylglycerols and free fatty acid fractions of Pyrosoma atlanticum and corresponding structure of the main phytoplankton taxa. Selection of fatty acid is based on stepwise discriminant analysis of the phytoplankton taxa (see text). n: number of replicates; -: not present or detectable

\begin{tabular}{|lcccccc|}
\hline $\begin{array}{l}\text { Fatty } \\
\text { acids }\end{array}$ & $\begin{array}{c}\text { Triacyl } \\
\text { glycerol } \\
(\mathrm{n}=3)\end{array}$ & $\begin{array}{c}\text { Free fatty } \\
\text { acids } \\
(\mathrm{n}=3)\end{array}$ & $\begin{array}{c}\text { Diatoms } \\
(\mathrm{n}=104)\end{array}$ & $\begin{array}{c}\text { Dinofla- } \\
\text { gellates } \\
(\mathrm{n}=36)\end{array}$ & $\begin{array}{c}\text { Prymnesio- } \\
\text { phytes } \\
(\mathrm{n}=36)\end{array}$ & $\begin{array}{c}\text { Chloro- } \\
\text { phytes } \\
(\mathrm{n}=21)\end{array}$ \\
\hline $14: 0$ & $8.72 \pm 2.74$ & $5.5 \pm 4.80$ & $20.0 \pm 4.47$ & $13.3 \pm 3.65$ & $23.3 \pm 4.82$ & $5.41 \pm 2.33$ \\
$16: 1 \mathrm{n}-7$ & $4.23 \pm 0.65$ & $1.99 \pm 1.42$ & $30.7 \pm 5.54$ & $9.87 \pm 3.14$ & $16.2 \pm 4.02$ & $11.3 \pm 3.36$ \\
$16: 2 \mathrm{n}-6$ & $0.49 \pm 0.08$ & $0.39 \pm 0.59$ & $0.21 \pm 0.46$ & $0.21 \pm 0.46$ & $0.38 \pm 0.61$ & $4.53 \pm 2.13$ \\
$16: 3 \mathrm{n}-3$ & - & - & $0.17 \pm 0.41$ & $0.32 \pm 0.56$ & $0.82 \pm 0.91$ & $12.8 \pm 3.58$ \\
$16: 3 \mathrm{n}-4$ & - & - & $12.9 \pm 3.59$ & - & $1.83 \pm 1.35$ & - \\
$16: 4 \mathrm{n}-1$ & $0.13 \pm 0.01$ & $0.06 \pm 0.05$ & $7.88 \pm 2.81$ & - & $0.44 \pm 0.66$ & $1.75 \pm 1.32$ \\
$16: 4 \mathrm{n}-3$ & $0.58 \pm 0.02$ & $0.18 \pm 0.13$ & $0.31 \pm 0.56$ & $1.92 \pm 1.38$ & $0.09 \pm 0.29$ & $11.2 \pm 3.35$ \\
$18: 0$ & $1.55 \pm 0.23$ & $1.65 \pm 2.07$ & $3.51 \pm 1.87$ & $9.37 \pm 3.06$ & $4.76 \pm 2.18$ & $2.94 \pm 1.71$ \\
$18: 1 \mathrm{n}-9$ & $5.60 \pm 0.40$ & $5.00 \pm 1.57$ & $8.14 \pm 2.85$ & $15.4 \pm 3.92$ & $21.1 \pm 4.59$ & $14.7 \pm 3.83$ \\
$18: 2 \mathrm{n}-6$ & $3.99 \pm 0.26$ & $1.82 \pm 0.49$ & $5.02 \pm 2.24$ & $9.53 \pm 3.09$ & $11.2 \pm 3.35$ & $18.4 \pm 4.29$ \\
$18: 3 \mathrm{n}-6$ & $0.20 \pm 0.07$ & $0.12 \pm 0.04$ & $1.86 \pm 1.36$ & $0.66 \pm 0.81$ & $2.64 \pm 1.62$ & $6.34 \pm 2.52$ \\
$18: 4 \mathrm{n}-3$ & $10.53 \pm 0.92$ & $2.42 \pm 0.33$ & $6.26 \pm 2.50$ & $11.7 \pm 3.43$ & $15.3 \pm 3.91$ & $6.69 \pm 2.59$ \\
$18: 5 \mathrm{n}-3$ & $0.89 \pm 0.11$ & $0.07 \pm 0.04$ & - & $12.5 \pm 3.53$ & $4.80 \pm 2.19$ & - \\
$20: 5 \mathrm{n}-3$ & $4.67 \pm 0.18$ & $7.20 \pm 4.67$ & $23.0 \pm 4.80$ & $12.7 \pm 3.57$ & $10.8 \pm 3.28$ & $2.61 \pm 1.62$ \\
$22: 5 \mathrm{n}-6$ & $0.35 \pm 0.03$ & $0.47 \pm 0.26$ & $0.73 \pm 0.85$ & $0.09 \pm 0.29$ & $3.21 \pm 1.79$ & $0.22 \pm 0.47$ \\
$22: 6 \mathrm{n}-3$ & $21.96 \pm 1.06$ & $44.47 \pm 17.32$ & $6.07 \pm 2.46$ & $25.6 \pm 5.06$ & $11.6 \pm 3.40$ & $0.20 \pm 0.45$ \\
\hline
\end{tabular}

discriminant functions were enough to account for $100 \%$ of the total variance with a value of Wilks' $\lambda$ of 0.003 . Results from the discriminant analysis show that the different categories are well discriminated by the model, with $100 \%$ of the diatoms, dinoflagellates and prymnesiophytes, as well as $98 \%$ of the chlorophytes placed in their respective category (Table 6). Using this model it was possible to assign the 2 Pyrosoma atlanticum free fatty acid and triacylglycerol fractions to the dinoflagellates and the prymnesiophytes, respectively.

\section{DISCUSSION}

Pyrosomas are important tunicates that play a major role in food webs of many oceanic areas and in global biogeochemical cycles (Drits et al. 1992, Andersen 1998). Yet, they are among the least investigated of all invertebrates, with no information at all currently available on their energetics and metabolic processes in particular (Madin \& Deibel 1998). To our knowledge, no ecological or physiological studies of pyrosomas have been previously undertaken in the Indian Ocean, with the only little information currently available for this group coming mainly from the regions of the Mediterranean Sea (Gorsky et al. 1988, Andersen \& Sardou 1994), the southeast (Drits et al. 1992) and the northeast (Angel 1989) Atlantic Ocean.

Prior to this, only one study had been undertaken on the feeding dynamics of Pyrosoma atlanticum (Drits et al. 1992). Unlike this earlier study, which dealt with small colonies of 5 to $6.5 \mathrm{~cm}$ in length, our study deals with relatively large pyrosoma colonies, of 7.5 to $24 \mathrm{~cm}$ (average: $12.1 \pm 4.22$ [SD] $\mathrm{cm}$ ) in total length. Drits et al. (1992) reported only values for nighttime gut pigment content $(G)$ and these were very high, in the range of 2.6 to $3.9 \mu \mathrm{g}$ pigment colony $^{-1}$. By comparison, and even considering only nighttime measurements, our levels were significantly lower, never in excess of $1.6 \mu \mathrm{g}$ pigment colony ${ }^{-1}$ (Table 1 , Fig. 3). This was reflected in the estimated values of gut turnover time, which was only $0.75 \mathrm{~h}$ in the study of Drits et al. (1992), but 
Table 6. Predicted group classification from stepwise (forward selection) discriminant analysis of the triacylglycerols and free fatty acid classes of Pyrosoma atlanticum within the fatty acid structure of the main phytoplankton taxa

\begin{tabular}{|lccccc|}
\hline Group & $\begin{array}{c}\text { Group } \\
\text { size }\end{array}$ & Diatoms & $\begin{array}{c}\text { Prymnesio- } \\
\text { phytes }\end{array}$ & $\begin{array}{c}\text { Dinofla- } \\
\text { gellates }\end{array}$ & $\begin{array}{c}\text { Chloro- } \\
\text { phytes }\end{array}$ \\
\hline Diatoms & 104 & $104(100 \%)$ & 0 & 0 & 0 \\
Prymnesiophytes & 36 & 0 & $36(100 \%)$ & 0 & 0 \\
Dinoflagellates & 36 & 0 & 0 & $36(100 \%)$ & 0 \\
Chlorophytes & 21 & 0 & $1(4.7 \%)$ & 0 & $20(95.3 \%)$ \\
Triacylglycerols & & & $3(100 \%)$ & $3(100 \%)$ & \\
Free fatty acids & & & & 3 & \\
\hline
\end{tabular}

about $1.4 \mathrm{~h}$ in our case. Gut pigment destruction had not been measured previously in any of the pyrosomas, including the $P$. atlanticum population investigated by Drits et al. (1992). Our measurements are, therefore, the first ever reported for this group of tunicates and range from 54 to almost $100 \%(79.7 \pm 18.8$ [SD] \%) of the total pigment ingested. These values are closer to those observed in some crustaceans (Mayzaud \& Razouls 1992, Perissinotto 1992) than to those previously observed in the salp Salpa thompsoni (6 to $41 \%$, Perissinotto \& Pakhomov 1998). They are, however, not very different to the levels obtained for the appendicularion Oikopleura vanhoeffeni (61 to $77 \%$, Bochdansky et al. 1998) and the salp Cyclosalpa bakeri (55 to 60\%, Madin \& Purcell 1992).

Although daily ingestion rates were similar in the 2 studies, i.e. $39.6 \pm 17.3$ (SD) $\mu \mathrm{g}$ pigment colony ${ }^{-1} \mathrm{~d}^{-1}$ in the south Indian Ocean versus $41.3 \mu \mathrm{g}$ pigment colony ${ }^{-1} \mathrm{~d}^{-1}$ in the southeast Atlantic (Drits et al. 1992), the respective estimates of clearance rates were very different: $204 \pm 91$ (SD) versus $55 \mathrm{l} \mathrm{colony}^{-1} \mathrm{~d}^{-1}$ (assuming that colonies fed only during nighttime hours in both cases). The volumes swept clear in our Pyrosoma atlanticum population were, therefore, about 4 times higher than those observed in the Atlantic population. Tunicate clearance rates are notably among the highest in the zooplankton and increase exponentially with the length of the individual (Madin \& Deibel 1998). While the Atlantic population investigated by Drits et al. (1992) had an average length of $5.5 \mathrm{~cm}$, the average length of the colonies used in our feeding measurements ranged from 9.3 to $20 \mathrm{~cm}$ (Table 1). As the internal volume of a colony increases as a power function of length (Madin \& Deibel 1998), the clearance rates observed in our study are well in the range of values that would be derived from a size-extrapolation of the rates obtained in the Atlantic colonies by Drits et al. (1992).

It is likely, however, that our estimates were affected by the very low chl a concentrations in the water (Table 1) and the only coarse vertical resolution in the distribution of Pyrosoma atlanticum that was possible to obtain during the study. This resulted in the integration of all values over a standard depth of $100 \mathrm{~m}$ (Table 1). Drits et al. (1992) had previously shown how dramatically values can change when a population that is concentrated over a very shallow water-layer (e.g. upper $10 \mathrm{~m}$ ) is assumed to be feeding through the entire euphotic layer. A similar effect would be reflected in the estimates of impact on phytoplankton biomass and production. Indeed, in our study these are quite low, generally $<1 \%$ apart from those obtained at Stn G4, which range between 5 and $6 \%$ of total standing stock and production, respectively (Table 1). By comparison, Drits et al. (1992) obtained maximum estimates of $53 \%$ of total standing stock when considering $P$. atlanticum swarms concentrated within the top $10 \mathrm{~m}$ layer.

As mentioned above, a detailed vertical sampling resolution was not possible during our study. Therefore, no information could be obtained on the depths and amplitudes of the vertical migration of the south Indian Ocean population of Pyrosoma atlanticum. Available information from elsewhere shows clearly, however, that this species exhibits a marked diel migratory pattern, with amplitudes related to colony size and ranging from 90 to $760 \mathrm{~m}$, at least in the Mediterranean region (Andersen \& Sardou 1994). A clear diel cycle in the feeding pattern of $P$. atlanticum was observed during our study, with nighttime gut pigment contents on average 1.83 times higher than daytime ones (Fig. 3). Despite the relatively small number of observations available, this difference is highly significant (Student's $t$-test, $\mathrm{p}<0.01$ ) and suggests the strong possibility of an endogenous feeding rhythm linked to the migratory behaviour of this species. This has not been reported before, as all the values reported in the study of Drits et al. (1992) were from colonies collected during nighttime only.

Size-fractionated feeding experiments showed a consistent preferential uptake of algal cells larger than $10 \mu \mathrm{m}$ in diameter, compared to those smaller than this size (Table 2). This is consistent with the general observation that, although tunicates are able to retain particles even smaller than $1 \mu \mathrm{m}$ in diameter, their highest retention efficiency is for the larger part of the size spectrum (Harbison \& McAlister 1979, Andersen 1998). Dietary algal group dominance was successfully elucidated during the study using lipid analysis (Tables 3 to 5). Pyrosoma atlanticum does not accumulate large lipid stores. Most lipids recorded from this species are polar lipids related to membrane structure (Table 3). The few reports of lipids available for gelati- 
nous zooplankton suggest a lipid content ranging from 1 to $12 \%$ of dry weight (Phleger et al. 1998, Jeffs et al. 2004). This is consistent with the hypothesis that tunicates from oligotrophic waters may exhibit high biomass turnover rates, as an alternative strategy to energy storage (Madin \& Deibel 1998). Alternately, some transparent zooplankton also have been found to store polar lipids, rather than the neutral lipid classes that more commonly serve as energy stores (Jeffs et al. 2001).

Fatty acids, as trophic markers, are used in a qualitative way to reveal information on feeding preferences and the ingestion of food items. Polyunsaturated fatty acids originating from phytoplankton can be deposited unchanged in the neutral lipid fraction and, to a lesser extent, in the polar fractions of primary and secondary consumers (Dalsgaard et al. 2003). It is well established that certain fatty acids found in zooplankton species originate from phytoplankton diets, such as palmitoleic acid, $16: 1 \mathrm{n}-7$, and $\mathrm{C}_{16}$ polyunsaturated fatty acids (trophic markers for diatoms), octadecatetraeonic acid (18:4n-3 for autotrophic flagellates), octadecapentaenoic acid (18:5n-3 for dinoflagellates and some prymnesiophytes; Joseph 1975, Mayzaud et al. 1976, Volkman et al. 1981).

The use of specific markers is, however, problematic with grazers, since it is difficult to establish dominant food sources. In the case of the Pyrosoma atlanticum population sampled in the Agulhas Front during February 1999, the high content of chloropigments found in the zooids suggest a predominantly phytoplankton diet. The apparent gut turnover time of $1.4 \mathrm{~h}$, observed in the colonies investigated, is indicative of an active digestion sequence with rapid production of free fatty acids and storage of triacylglycerols. Hence, trophic interactions are likely to be best detectable in these 2 lipid classes. The presence of phytosterols is consistent with such an interpretation, since they show specificity to taxonomic groups (Volkman 1986, Jones et al. 1994).

In terms of fatty acid composition, the neutral lipids in Pyrosoma atlanticum showed evidence of specific markers for diatoms (C16 PUFA), dinoflagellates (22:6n-3, 18:5n-3) and prymesiophytes (18:1n-9, 18:4n3). Results from the LDA indicate that the prevailing phytoplankton consumed were essentially prymnesiophytes and dinoflagellates. This is consistent with the results of the phytoplankton community structure undertaken during the study period. These show that prymnesiophytes (mainly Emiliana huxleyi and Gephyrocapsa oceanica) and dinoflagellates (Gymnodinium spp., Girodinium spp., Prorocentrum spp. and Oxytoxum laticeps) were the dominant groups in such oligotrophic waters, while both diatoms and nanoflagellates were scarcely represented throughout the survey area (Fiala et al. 2004). These trophic links agree with the sterol composition data, since dinoflagellates and prymnesiophytes contain, besides cholesterol, also 24-methylcholesta-5,22E-dien-3 $\beta$,-ol, cis 22 dehydrocholesterol and 24-ethylcholesta-5,22E-dien$3 \beta$,-ol (Volkman 1986). The absence, however, of the typical dinoflagellate signature dinosterol in the pyrosomas may indicate that flagellates other than dinoflagellates (e.g. nanoflagellates) were important component of the diet of $P$. atlanticum. Interestingly, dinosterol was also only a minor $(\leq 1 \%)$ sterol in analyses of $P$. atlanticum obtained from New Zealand waters (Jeffs et al. 2004). A number of dinoflagellate species do not contain dinosterol (Piretti et al. 1997, Mansour et al. 1999). An alternate explanation may be that species of dinoflagellates lacking dinosterol dominated this component of its diet, or pyrosomas may actually lack suitable enzymes for digesting dinoflagellates. Both possibilities agree with the fatty acid data.

Earlier reports had indicated that pyrosomas may be able to feed exclusively on prymnesiophytes (coccolothophores, Dhandapani 1981). However, in their south Atlantic study Drits et al. (1992) had identified in the faecal pellets of Pyrosoma atlanticum centric diatoms, silico-flagellates and even fragments of small crustaceans, apart from the coccolithophores. Our data, therefore, seem to confirm the prominent role of prymnesiophytes in the diet of pyrosomes, but also an ability to ingest a wider range of phytoplankton groups, possibly on an opportunistic basis. The potential role of any heterotrophic material remains, however, to be confirmed, as no indication of such a contribution was obtained during this study.

An interesting observation was made while carrying out the grazing experiments. In the process of identification of the zooid units, pyrosome colonies dissected shortly after collection (within a few hours) and observed under an inverted microscope at high magnification exhibited large numbers of ciliate protozoans, possibly of the genus Strombidium (Fig. 4). These were seen moving at relatively high speed in the interstitial space amongst zooids. This is a new record for pyrosomas, although associations of other protozoans and crustaceans with pyrosomas have been reported previously, but never with evidence of symbiotic/ectoparasitic activity. The penaeid shrimp Solenocera membranacea was the first species to be observed in the cloacal cavity of Pyrosoma atlanticum in the Gulf of Naples (Monticelli \& Lo Bianco 1901). Hyperiid amphypods of the genera Phronima and Phronimella have also been found regularly within $P$. atlanticum throughout the Mediterranean Sea (Trégouboff \& Rose 1957). More recently, 5 specimens of the penaeid genus Funchalia have been found inside living $P$. atlanticum taken off Tenerife, Canary Islands (Lindley et al. 2001). 
Concerning protozoans, reports available for the Mediterranean population of Pyrosoma atlanticum indicate that at least 3 'parasitic' ciliate species have been recorded inside colonies (Harbison 1998). These include the microthoracid Conchophrys davidoffi (Chatton 1911) and the apostomatids Tunicophrya sessilis (Collin 1912, Trégouboff 1916) and Actinobranchium salparum pyrosomae (Trégouboff 1916). Unfortunately, the nature of the association between Strombidium sp. and P. atlanticum could not be established during the ANTARES-4 study. It remains to be seen, therefore, whether a simple opportunistic intrusion or a more stable relationship is involved. The latter could be in the form of parasitism, but inverse predation or symbiosis are also not to be excluded, as ciliates are clearly in the size range (about 100 to $200 \mu \mathrm{m}$ ) of retention by the feeding branchial basket and can potentially be utilized by zooids as a food source. This aspect requires further investigation.

Acknowledgements. We thank the French CNRS, the South African NRF and the University of KwaZulu-Natal (Durban, South Africa) for providing funds for this study. We are particularly grateful to P. Vorwerk for his invaluable assistance at sea, and to our cruise colleagues Y. Park, M. Fiala and B. Griffiths for supplying us with, and allowing to use data on physical parameters, chl $a$ and primary production, respectively. Finally, we thank the captain, officers and crew of the RV 'Marion Dufresne' for their assistance and cooperation during the ANTARES-4 voyage.

\section{LITERATURE CITED}

Ackman RG (1981) Application of flame ionization detectors to thin layer chromatography on coated quartz rods. Methods Enzymol 72:205-252

Andersen V (1998) Salp and pyrosomid blooms and their importance in biogeochemical cycles. In: Bone Q (ed) The biology of pelagic tunicates. Oxford University Press, Oxford, p 125-137

Andersen V, Sardou J (1994) Pyrosoma atlanticum (Tunicata, Thaliacea): diel migration and vertical distribution as a function of colony size. J Plankton Res 16:337-349

Angel MV (1989) Vertical profiles of pelagic communities in the vicinity of the Azores Front and their implications to deep ocean ecology. Prog Oceanogr 22:1-46

Bligh EG, Dyer WJ (1959) A rapid method of total lipid extraction and purification. Can J Biochem Physiol 37:911-917

Bochdansky AB, Deibel D, Hatfield EA (1998) Chlorophyll a conversion and gut passage time for the pelagic tunicate Oikopleura vanhoeffeni (Appendicularia). J Plankton Res 20:2179-2197

Bone Q (1998) Locomotion, locomotor muscles, and buoyancy. In: Bone Q (ed) The biology of pelagic tunicates. Oxford University Press, Oxford, p 35-53

Childerhouse S, Dix B, Gales N (2001) Diet of New Zealand sea lions (Phocarctos hookeri) at the Auckland Islands. Wildl Res 28:291-298

Clementson LA, Parslow JS, Griffiths FB, Lyne VD, Mackey DJ, Harris GP, McKenzie DC, Rintoul S (1998) Controls on phytoplankton production in the Australasian sector of the Subtropical Convergence. Deep-Sea Res I 45: 1627-1661

Conover RJ, Durvasula R, Roy S, Wang R (1986) Probable loss of chlorophyll-derived pigments during passage through the gut of zooplankton and some of the consequences. Limnol Oceanogr 31:878-887

Dalsgaard J, St John M, Kattner G, Müller-Navarra D, Hagen W (2003) Fatty acid trophic markers in the pelagic marine environment: a review. Adv Mar Biol 46:225-340

Dam HG, Peterson WT (1988) The effect of temperature on the gut clearance rate constant of planktonic copepods. J Exp Mar Biol Ecol 123:1-14

Dhandapani P (1981) The role of Thaliacea in the marine plankton ecosystem. In: Proceedings of the Symposium on Ecological Animal Populations, Part 1. Zoological Survey of India, Calcutta, p 51-71

Drits AV, Arashkevich EG, Semenova TN (1992) Pyrosoma atlanticum (Tunicata, Thaliacea): grazing impact on phytoplankton standing stock and role in organic carbon flux. J Plankton Res 14:799-809

Fiala M, Kopczyńska EE, Oriol L, MacHado MC (2004) Phytoplankton variability in the Crozet Basin frontal zone (Southwest Indian Ocean) during austral summer. J Mar Syst 50:243-261

Gorsky G, Dallot S, Sardou J, Fenaux R, Carré C, Palazzoli I (1988) C and $\mathrm{N}$ composition of some northwestern Mediterranean zooplankton and micronekton species. J Exp Mar Biol Ecol 124:133-144

Harbison GR (1998) The parasites and predators of Thaliacea. In: Bone Q (ed) The biology of pelagic tunicates. Oxford University Press, Oxford, p 187-214

Harbison GR, McAlister VL (1979) The filter-feeding rates and particle retention efficiencies of three species of Cyclosalpa (Tunicata, Thaliacea). Limnol Oceanogr 24:875-892

Hedd A, Gales R (2001) The diet of shy albatrosses (Thalassarche cauta) at Albatross Island, Tasmania. J Zool (Lond) 253:69-90

James GD, Stahl JC (2000) Diet of southern Buller's albatross (Diomedea bulleri bulleri) and the importance of fishery discards during chick rearing. NZ J Mar Freshw Res 34: $435-454$

Jeffs AG, Nichols PD, Bruce M (2001) Lipid reserves used by pueruli of the spiny lobster Jasus edwardsii in crossing the continental shelf of New Zealand. Comp Biochem Physiol A 129:305-311

Jeffs AG, Nichols PD, Mooney BD, Philipps KL, Phleger CF (2004) Identifying potential prey of the pelagic larvae of the spiny lobster Jasus edwardsi using signature lipids. Comp Biochem Physiol B137:487-507

Jones GJ, Nichols PD, Shaw PM (1994) Analysis of microbial sterols and hopanoids. In: Goodfellows M, O'Donnell AG (eds) Chemical methods in prokaryotic systematics. John Wiley and Sons, New York, p 163-195

Joseph JD (1975) Identification of 3, 6, 9, 12, 15-octadecapentaenoic acid in laboratory-cultured photosynthetic dinoflagellates. Lipids 10:395-403

Lindley JA, Hernandez F, Scatllar J, Docoito J (2001) Funchalia sp. (Crustacea: Penaeidae) associated with Pyrosoma atlanticum (Thaliacea: Pyrosomidae) off the Canary Islands. J Mar Biol Assoc UK 81:173-174

Madin LP, Deibel D (1998) Feeding and energetics of thaliacea. In: Bone Q (ed) The biology of pelagic tunicates. Oxford University Press, Oxford, p 81-103

Madin LP, Purcell JE (1992) Feeding, metabolism and growth of Cyclosalpa bakeri in the subarctic Pacific. Limnol Oceanogr 37:1236-1251

Mansour MP, Volkman JK, Jackson AE, Blackburn SI (1999) 
The fatty acid and sterol composition of 5 marine dinoflagellates. J Phycol 35:710-720

Martinucci GB, Dallai R, Burighel P, Casagrande L (1992) Ciliary specializations in branchial stigmatal cells of protochordates. Tissue Cell 24:229-241

Mayzaud P, Razouls S (1992) Degradation of gut pigment during feeding by a subantarctic copepod: importance of feeding history and digestive acclimation. Limnol Oceanogr 37:393-404

Mayzaud P, Eaton CA, Ackman RG (1976) The occurrence and distribution of octadecapentaenoic acid in a natural plankton population. a possible food chain index. Lipids 11:858-862

Mayzaud P, Boutoute M, Alonzo F (2003) Lipid composition of the Antarctic euphausiids Euphausia vallentini and Thysanoessa macrura during summer in the Indian sector of the Southern Ocean. Antarct Sci 15:463-475

Monticelli FS, Lo Bianco S (1901) Sullo sviluppo dei peneidi del Golfo di Napoli (note riassuntive). Monit Zool Ital 11:23-31 (in Italian)

Morrison WR, Smith LM (1964) Preparation of fatty acid methyl esters and dimethylacetals from lipids with boron fluoride-methanol. J Lipid Res 5:600-608

Perissinotto R (1992) Mesozooplankton size-selectivity and grazing impact on the phytoplankton community of the Prince Edward Archipelago (Southern Ocean). Mar Ecol Prog Ser 79:243-258

Perissinotto R, Pakhomov EA (1998) The trophic role of the tunicate Salpa thompsoni in the Antarctic marine eco-

Editorial responsibility: Howard Browman (Associate Editorin-Chief), Storebø, Norway system. J Mar Syst 17:361-374

Perissinotto R, Pakhomov EA, McQuaid CD, Froneman PW (1997) In situ grazing rates and daily ration of Antarctic krill Euphausia superba feeding on phytoplankton at the Antarctic Polar Front and the Marginal Ice Zone. Mar Ecol Prog Ser 160:77-91

Perissinotto R, Mayzaud P, Labat JP, Razouls S (2001) Grazing dynamics of Euphausia spinifera in the region of the Subtropical Convergence and the Agulhas Front. Can J Fish Aquat Sci 58:273-281

Phleger CF, Nichols PD, Virtue P (1998) Lipids and trophodynamics of Antarctic zooplankton. Comp Biochem Physiol B 120:311-323

Piretti MV, Pagliuca G, Boni L, Pistocchi R, Diamante M, Gazzoti T (1997) Investigation of 4-methyl sterols from cultured dinoflagellate algal strains. J Phycol 33:61-67

Tirelli V, Mayzaud P (1998) Gut pigment destruction by the copepod Acartia clausi. J Plankton Res 20:1953-1961

Trégouboff G, Rose M (1957) Manuel de planctonologie méditerranéenne, Tome 1, Texte. CNRS, Paris

van Soest RWM (1981) A monograph of the order Pyrosomatida (Tunicata, Thaliacea). J Plankton Res 3:603-631

Volkman JK (1986) A review of sterol markers for marine and terrigenous organic matter. Org Geochem 9:83-99

Volkman JK, Smith DJ, Eglinton G, Forsberg TEV, Corner EDS (1981) Sterol and fatty acid composition of 4 marine haptophycean algae. J Mar Biol Assoc UK 61:509-528

Zar JH (1984) Biostatistical analysis. Prentice-Hall, Englewood Cliffs, NJ

Submitted: September 25, 2006; Accepted: November 2, 2006 Proofs received from author(s): January 16, 2007 